\title{
Determinan Belanja Modal Bidang Kesehatan Daerah Provinsi Jawa Timur
}

Much. Adam Ferdiansyah ${ }^{*}$, Aden Hubbbil Choiri**

*Fakultas Ekonomi\&Bisnis, Universitas Airlangga, adamferdiansyahmochammad@gmail.com

**Fakultas Ekonomi\&Bisnis, Universitas Muhammadiyah Gresik

\section{ARTICLE INFO}

\section{Article history:}

Received 12 Februari 2020

Received in Revised 15 Maret 2020

Accepted 13 April 2020

\section{Keywords:}

Capital expenditure in health sector,

Localy-generated revenue, General

allocation fund, and Special allocation fund

\section{A B S T R A C T}

This research examined the determinant model of capital expenditures in the health sector. Test of the determinant model rely on the premises of agency theory. The determinan variables consists a several factors namely locally-generated revenue, general allocation fund, and special allocation fund. Populations and samples which used in this study are city and district in east java province. The observation period are three years observation during 2015-2017. The model test used multiple regression. The result of the test showed that locally-generated revenue, general allocation fund and special allocation fund are determinant of capital expenditure in health sector. Locally-generated revenue and special allocation fund showed positive determination. Meanwhile, general allocation fund indicate negative impact.

Tujuan penelitian ini adalah menguji model determinan belanja modal bidang kesehatan. Model determinan belanja modal bidang kesehatan ditinjau dari kerangka teori keagenan. Variabel determinan yang diuji yakni pendapatan asli daerah, dana alokasi umum dan dana alokasi khusus. Populasi dan sampel penelitian yang digunakan sebagai objek amatan adalah daerah provinsi Jawa Timur. Periode amatan mencakup tiga periode yakni 2015-2017. Pengujian model menggunakan uji regresi linier berganda. Hasil uji menunjukkan bahwa secara empiris variabel pendapatan asli daerah, dana alokasi umum dan dana alokasi khusus merupakan determinan dari alokasi belanja modal bidang kesehatan. Pendapatan asli daerah dan dana alokasi khusus menunjukkan determinasi positif. Sementara itu, dana alokasi umum menunjukkan determinasi negatif. 


\section{PENDAHULUAN}

Tujuan utama penyelenggaraan pemerintahan adalah mencapai kesejahteraan bagi seluruh masyarakat (social welfare). Kesejahteraan yang merupakan kepentingan umum hanya dapat dicapai dengan memberikan layanan kepada masyarakat atau layanan publik. Salah satu bidang layanan publik yang menjadi indikator penting kesejahteraan masyarakat adalah kesehatan (Nuriyanto, 2014).

Tingkat kesehatan masyarakat dapat menentukan pencapaian elemen dasar kesejahteraan yang lain, yakni pendapatan dan pendidikan. Masyarakat yang sehat cenderung lebih produktif dibandingkan yang kurang sehat. Produktivitas yang baik dapat meningkatkan pendapatan. Pendapatan yang cukup dapat menunjang elemen ketiga yakni pendidikan. Tingkat kesehatan dapat dikatakan menentukan tingkat kesejahteraan suatu masyarakat (Hardiyansyah, 2018

Langkah strategis yang dapat mendukung percepatan pencapaian peningkatan kualitas layanan kesehatan sangat diperlukan. Salah satu upaya yang dilakukan adalah mempertimbangkan pergeseran strategi dari pemenuhan hal-hal yang bersifat rutin (operasional/konsumtif) menuju kepada pemenuhan kebutuhan yang bersifat jangka panjang (Sudika \& Budhiarta, 2017). Pergeseran langkah strategis di bidang kesehatan dapat dimulai dengan memberanikan diri untuk mengambil kebijakan yang visioner. Langkah ini dapat dicapai dengan meningkatkan alokasi belanja modal di bidang kesehatan (Martani \& Dwirandra, 2015). Belanja modal merupakan komponen belanja yang bersifat langsung, di mana outputnya adalah aset tetap. Belanja modal dapat memberikan beberapa manfaat seperti percepatan pembangunan (dalam hal ini di bidang kesehatan), meningkatkan partisipasi publik, serta peningkatan pelayanan kesehatan bagi masyarakat. Oleh karena itu, penting bagi pemerintah untuk beralih strategi dengan menekan belanja rutin serta meningkatkan belanja modal, khususnya di bidang kesehatan (Widiasih \& Gayatri, 2017).

Peningkatan belanja modal nyatanya tidak dapat berdiri sendiri. Belanja negara maupun daerah juga ditentukan banyak faktor. Berdasarkan kajian teoritis, faktor yang robust dalam menentukan belanja modal adalah tingkat kemandirian, efektivitas dan efisiensi dari suatu daerah (Eksandy, et.al., 2019; Sari \& Wirama, 2018; Palupi \& Sulardi, 2018; Widiasih \& Gayatri, 2017; Martani \& Dwirandra, 2015; serta Sholikhah \& Wahyudin, 2014).

Beberapa riset terdahulu membuktikan bahwa tingkat kemandirian menjadi faktor penentu alokasi belanja modal. Semakin tinggi tingkat kemandirian dari suatu daerah dapat memberikan fleksibilitas dalam hal alokasi dana untuk belanja modal (Sari \& Wirama, 2018; Widiasih \& Gayatri, 2017; Sholikhah \& Wahyudin, 2014). Tingkat kemandirian yang direpresentasikan dengan Pendapatan Asli Daerah (PAD) menunjukkan adanya keberhasilan dalam mengelola keuangan suatu daerah.

Perbedaan riset ini dengan riset sebelumnya dapat diidentifikasi dari beberapa hal seperti fokus, periode amatan dan objek amatan. Fokus riset ini adalah alokasi belanja modal di bidang kesehatan, di mana pada penelitian sebelumnya hanya meneliti belanja modal secara umum. Perbedaan berikutnya adalah dari segi periode amatan, riset ini menggunakan tiga tahun periode amatan, yakni selama 2015-2017. Objek penelitian ini juga relatif berbeda dengan beberapa penelitian sebelumnya yang telah dipaparkan di atas, yakni kabupaten/kota di provinsi Jawa Timur. 
Kerangka Pemikiran dan Pengembangan Hipotesis

Jensen dan Meckling (1976) mengembangkan sebuah teori yang disebut Teori Keagenan. Teori ini menjelaskan adanya berbagai macam pihak dalam perusahaan. Berbagai pihak tersebut mempunyai kepentingan yang berbeda. Pihak-pihak tersebut dapat digolongkan dalam dua kelompok utama yaitu prinsipal dan agen. Prinsipal dalam hal ini adalah pemegang saham, sedangkan agen adalah pengelola atau manajer perusahaan. Relevansi teori ini dalam konteks sektor publik dikemukakan oleh Teori keagenan yang dikemukakan oleh Palupi \& Sulardi (2018) Hubungan keagenan tersebut juga terjadi di pemerintahan antara rakyat sebagai prinsipal dan pemerintah sebagai agen. Pemerintah dapat melakukan kebijakan yang hanya mementingkan pemerintah dan penguasa serta mengorbankan kepentingan dan kesejahteraan rakyat. Untuk mengurangi konflik maka diperlukan monitoring oleh prinsipal atas apa yang dilakukan oleh agen.

PAD dapat menggambarkan tingkat kemandirian suatu daerah (Martini \& Dwirandra, 2015). Kemandirian suatu daerah akan sangat menentukan preferensi kebijakan yang diambil oleh pemerintah daerah. Kemandiran dalam hal ini merujuk pada kemandirian finansial. Daerah yang mampu menunjukkan kemandirian finansial tentunya lebih memiliki fleksibilitas dalam penganggarannya.

Peningkatan pelayanan kesehatan dapat ditunjang ketika daerah mampu mengelola sumbersumber ekonominya. Perspektif Teori Keagenan dapat menjadi penjelas asosiasi antara PAD dengan belanja modal bidang kesehatan. Berdasarkan sudut pandang monitoring solution, kemandirian dapat dijadikan sebagai indikator kinerja pemerintah daerah dalam mengelola sumber ekonominya (Martini \& Dwirandra, 2015; Palupi \& Sulardi (2018). Semakin tinggi tingkat kemandirian suatu daerah, maka semakin memberikan fleksibilitas dalam pengganggaran modalnya, khususnya pada bidang kesehatan.

Dari penjelasan tersebut dapat disimpulkan bahwa secara harfiah penentuan pengelolaan PAD atau kemandirian daerah dapat menentukan alokasi belanja modal untuk kesehatan. Penelitian Sari \& Wirama (2018); Widiasih \& Gayatri (2017); Sholikhah \& Wahyudin (2014) menemukan bahwa tingkat kemandirian yang direpresentasikan dengan PAD menunjukkan pengaruh terhadap alokasi belanja modal. Berdasarkan uraian tersebut, maka dapat dirumuskan hipotesis sebagai berikut :

\section{H1 : Pendapatan Asli Daerah (PAD) berpengaruh terhadap alokasi belanja modal}

Semakin tinggi transfer dana dari pusat ke daerah dalam bentuk DAU (Dana Alokasi Umum), maka semakin memberikan dukungan terhadap pendanaan belanja modal. Beberapaa riset sebelumnya membuktikan secara empiris asosisasi dari DAU terhadap belanja modal (Gani \& Kristanto, 2013; Sudika \& Budiartha, 2017; Palupi \& Sulardi, 2018). Apabila merujuk pada penjelasan tersebut, maka dapat dirumuskan hipotesis sebagai berikut :

\section{H2 : Dana Alokasi Umum (DAU) berpengaruh terhadap alokasi belanja modal}

Seperti halnya Dana Alokasi Umum (DAU), Dana Alokasi Khusus (DAK) juga memainkan peran yang sama. Unsur monitoring dari Teori Keagenan dapat dilihat dari ada atau tidaknya komitmen pemerintah daerah untuk mempercepat pembangunan melalui kebijakan-kebijakan yang sifatnya jangka panjang, misalnya seperti pembangunan fasilitas kesehatan. DAK dapat menjadi sumber dana untuk membiayai program-program yang memiliki manfaat jangka panjang. 
Monitoring terhadap kinerja pemerintah daerah dapat dilakukan dengan menilai sejauh mana transfer dana dari pusat dapat mendorong program yang dicanangkan oleh pemerintah daerah. Fenomena yang terjadi adalah cenderung kurangnya preferensi untuk mengalokasikan dana untuk belanja modal karena relatif besar yang harus dikeluarkan. Hal ini dibuktikan dengan persentase belanja modal yang tidak lebih besar daripada belanja pegawai maupun barang (Martini \& Dwirandra, 2015). Berdasarkan uraian di atas, tingkat DAK memiliki asosiasi dengan belanja modal. Beberapa riset sebelumnya juga mendukung secara empiris premis tersebut (Gani \& Kristanto, 2013; Sudika \& Budiartha, 2017; Palupi \& Sulardi, 2018). Berdasarkan pada penjelasan tersebut, maka hipotesis yang dapat dirumuskan adalah sebagai berikut :

H3 : Dana Alokasi Khusus (DAK) berpengaruh terhadap alokasi belanja modal

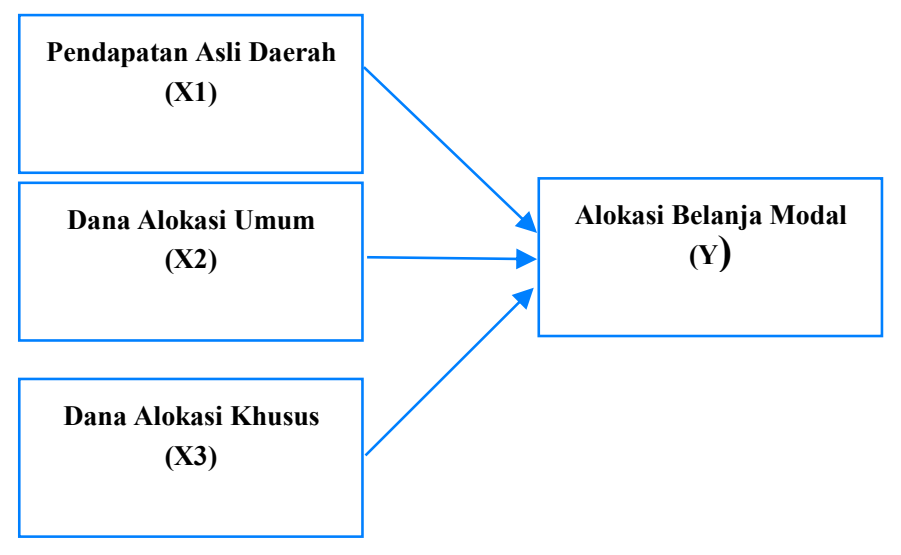

Gambar 1. Kerangka Pemikiran

\section{METODE}

\subsection{Pengumpulan Data dan Sampel Penelitian}

Penelitian dengan paradigma ini menghendaki pengujian teori dengan menggunakan variabel. Sifat dari penelitian ini adalah replikatif, yaitu membuktikan konsisten/inkonsistensi dari hasil penelitian sebelumnya. Tujuan akhirnya adalah memprediksi suatu fenomena. Selain itu penelitian kuantitatif dengan paradigma positivis ditujukan untuk melakukan generalisasi terhadap suatu objek dan fenomena yang diteliti (Kamayanti, 2016 : 13). Populasi yang telah dipilih oleh peneliti dalam penelitian ini adalah seluruh kabupaten/kota di provinsi Jawa Timur. Teknik pengambilan sampel seperti ini disebut sebagai purposive sampling. Data yang diperlukan peneliti untuk menguji hipotesis adalah data yang berasal dari dokumen, yaitu laporan keuangan. Sumber data dengan karakteristik seperti ini disebut sumber data sekunder (Sujarweni, 2015; 56).

\subsection{Variabel Penelitian}

Penelitian ini menggunakan 1 (satu) variabel dependen dan 3 (tiga) variabel independen. Variabel dependen yang digunakan dalam penelitian ini adalah Alokasi belanja modal (Y1). Variabel independen dalam penelitian ini Pendapatan asli daerah (X1), Dana alokasi umum (X2) dan Dana alokasi khusus. 


\subsection{Metode Analisis}

Data yang digunakan dalam penelitian ini nantinya akan dianalisis menggunakan regresi linier berganda. Alat yang digunakan untuk menganalisis data adalah software SPSS.

\section{HASIL DAN PEMBAHASAN}

Setelah dilakukan pengamatan, identifikasi, dan dokumentasi pada website resmi dan publikasi dari Badan Pusat Statistk (BPS) dan Direktorat Jenderal Perimbangan Keuangan (DJPK), diperoleh hasil sebagai berikut:

Tabel 1. Hasil Pemilihan Sampel

\begin{tabular}{lc}
\hline \hline \multicolumn{1}{c}{ Keterangan } & Jumlah \\
\hline Kabupaten/Kota di Jawa Timur & 38 \\
Kabupaten/Kota yang mempublikasikan data penelitian lengkap & 34 \\
Jumlah sampel terpilih & 34 \\
Jumlah sampel selama lima tahun periode penelitian (2015-2017) & 102 \\
Data outlier & 12 \\
Data akhir & 90 \\
\hline
\end{tabular}

Sumber: Data dari www.bps.or.id \& www.djpk.or.id diolah 2019

Dari tabel di atas, diperoleh informasi terkait dengan anggota populasi, yakni Kabupaten/Kota di provinsi Jawa Timur. Pada tabel tersebut diketahui bahwa jumlah Kabupaten/Kota di Jawa Timur adalah sebanyak 38 daerah. Dari jumlah tersebut, 29 diantaranya merupakan Kabupaten, sementara 9 daerah lainnya merupakan Kota. Hasil ini kemudian dikalikan dengan jumlah periode pengamatan yakni lima tahun pengamatan (2015, 2016 dan 2017). Dengan demikian jumlah data yang diobservasi adalah sebanyak 114 buah ( $38 \times 3$ tahun).

\subsection{Hasil Uji Statistik Deskriptif}

Dari hasil uji statistik deskriptif, diperoleh hasil seperti yang disajikan padda tabel di bawah ini.

Tabel 2. Hasil Uji Statistik Deskriptif

\begin{tabular}{lccccc}
\hline \hline \multicolumn{1}{c}{ Variabel } & N & Min. & Max. & Mean & $\begin{array}{c}\text { Std. } \\
\text { Deviatio } \\
\text { n }\end{array}$ \\
\hline Belanja Modal Kesehatan & 90 & 25,43 & 27,73 & 26,35 & 0,45 \\
Pendapatan Asli Daerah & 90 & 24,75 & 29,04 & 26,07 & 0,84 \\
Dana Alokasi Umum & 90 & 26,00 & 28,16 & 27,30 & 0,45 \\
Dana Alokasi Khusus & 90 & 22,69 & 26,89 & 25,43 & 0,79 \\
\hline
\end{tabular}

Sumber: Data output SPSS diolah

\subsection{Hasil Uji Normalitas}

Pada penelitian ini, pengujian normalitas data dilakukan dengan menggunakan uji Kolmogorovsmirnov test. Hasil uji normalitas disajikan pada tabel berikut: 
Tabel 3. Hasil Uji Normalitas

\begin{tabular}{lc}
\hline \hline \multicolumn{1}{c}{ Indikator } & \multicolumn{1}{c}{ Nilai } \\
\hline Asymp. Sig. 2-Tailed & 0,77 \\
\hline $\begin{array}{l}\text { Sumber: Data output SPSS } \\
\text { diolah }\end{array}$
\end{tabular}

Dengan melihat hasil yang diperoleh pada tabel di atas, maka dapat disimpulkan bahwa data yang digunakan dalam model regresi pada riset ini telah berdistribusi normal. Distribusi normalitas data dapat dilihat dari nilai Asymp. Sig (2-tailed) yang lebih besar daripada 0,05. Nilai Asymp. Sig (2-tailed) dari hasil pengujian menunjukkan angka 0,77 yang berarti lebih besar daripada 0,05 . .

\subsection{Hasil Uji Multikolinearitas}

Tabel 4. Hasil Uji Multikolinearitas

\begin{tabular}{lccc}
\hline \hline \multicolumn{1}{c}{ Variabel } & Tolerance & VIF & Note \\
\hline Pendapatan Asli Daerah & 0,51 & 1,95 & Non-Multikolinearitas \\
Dana Alokasi Umum & 0,34 & 2,92 & Non-Multikolinearitas \\
Dana Alokasi Khusus & 0,58 & 1,73 & Non-Multikolinearitas
\end{tabular}

Sumber: Data output SPSS diolah

Pada tabel di atas, diketahui besaran niali Tolerance dan VIF dari masing-masing variabel independen. Nilai Tolerance dari setiap variabel independen secara berturut-turut yakni $0,51,0,34$, dan 0,58. Hasil ini mengindikasikan bahwa model regresi telah terbebas dari asumsi multikolinearitas. Kesimpulan ini didasarkan pada nilai Tolerance yang lebih besar daripada 0,1.

\subsection{Hasil Uji Autokorelasi}

Tabel 5. Hasil Uji Autokorelasi-DW Test

\begin{tabular}{lccccc}
\hline \hline \multicolumn{1}{c}{ Variabel } & DL & DU & DW & 4-DU & Note \\
\hline Pendapatan Asli Daerah & 1,589 & 1,726 & 1,337 & 2,274 & $\begin{array}{c}\text { Autokore } \\
\text { lasi } \\
\text { Autokore } \\
\text { lasi }\end{array}$ \\
& 1,589 & 1,726 & 1,337 & 2,274 & $\begin{array}{c}\text { Autokore } \\
\text { lasi }\end{array}$ \\
Dana Alokasi Umum & 1,589 & 1,726 & 1,337 & 2,274 &
\end{tabular}

Dari hasil DW-Test, nilai Durnin Lower (DL) menunjukkan angka sebesar 1,589; sementara itu, nilai Durbin Uper (DU) sebesar 1,726; selain itu, diperoleh nilai DW hitung adalah sebesar 1,337. Dengan menggunakan kriteria tertinggi dari DW-Test untuk menentukan kesimpulan bahwa "tidak terjadi autokorelasi" rumus DU $<$ DW $<4$-DU digunakan. Ketika dimasukkan ke dalam rumus, hasil DW-Test menunjukkan nilai 1,726>1,337<2,274 (4-1,726). Dengan demikian dapat dikatakan bahwa model regresi terindikasi gejala autokorelasi 


\subsection{Hasil Uji Heteroskedastisitas}

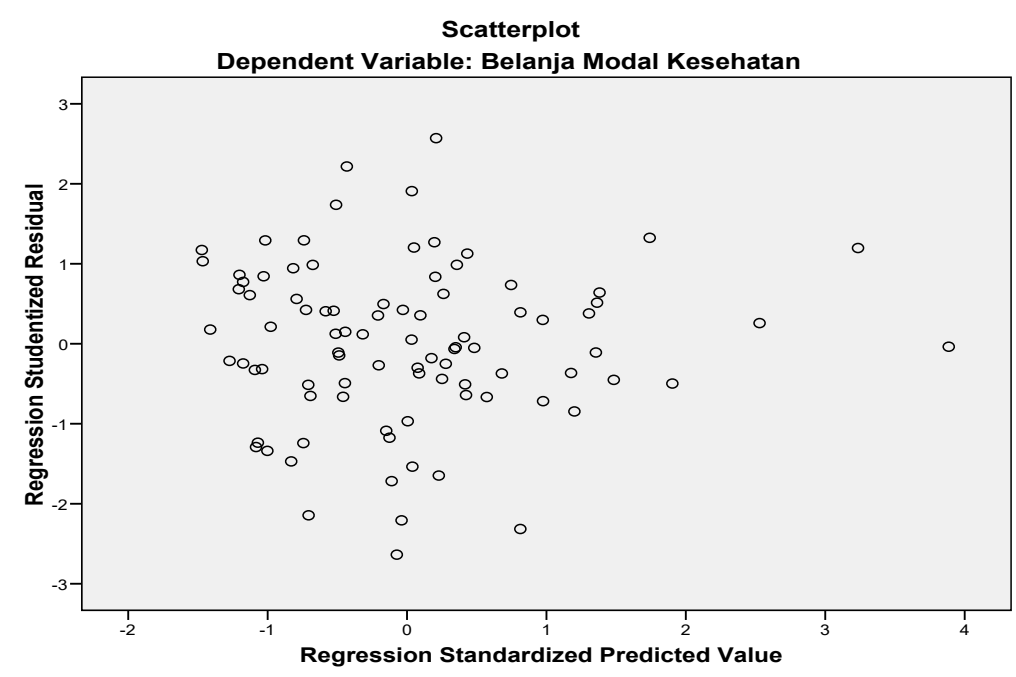

Gambar 1. Hasil Uji Heteroskedastisitas

Dari grafik scatter plot di atas, dapat ditarik kesimpulan bahwa model regresi dalam penelitian ini tidak terindikasi gejala Heteroskedastsitas. Data dalam model regresi ini dapat dikatakan mengalami Homoskedastisitas. Kesimpulan ini didasarkan atas hasil uji melalui analisis grafik scatter plot yang menunjukkan titik-titik (plot) data menyebar secara acak dan tidak membentuk pola tertentu.

\subsection{Hasil Uji Regresi Linier Berganda}

Hasil uji regresi linier berganda atas model penellitian diperoleh nilai koefisien regresi sebagaimana yang tertera pada tabel di bawah ini:

Tabel 6. Hasil Uji Regresi Multiple

\begin{tabular}{lc}
\hline \hline \multicolumn{1}{c}{ Variabel } & $\begin{array}{c}\text { Koefisie } \\
\text { n }\end{array}$ \\
\hline \multicolumn{1}{c}{ Constant } & 0,100 \\
Pendapatan Asli Daerah & 0,396 \\
Dana Alokasi Umum & $-0,284$ \\
Dana Alokasi Khusus & 0,220 \\
\hline Sumber: Data output SPSS diolah
\end{tabular}

Belanja modal kesehatan $=0,100+0,396 \mathrm{PAD}-0,284 \mathrm{DAU}+0,220 \mathrm{DAK}+e$

Berdasarkan perolehan nilai koefisien regresi yang telah diformulasikan ke dalam rumus model regresi pada penelitian ini, maka diperoleh beberapa kesimpulan berikut:

1. Nilai konstanta yang diperoleh adalah sebesar 0,100, hasil ini mengandung arti bahwa ketika tidak terjadi perubahan nilai pada variabel Pendapatan Asli Daerah (PAD) (X1), Dana Alokasi Umum (DAU) (X2), dan Dana Alokasi Khusus (DAK) (X3), maka variabel belanja modal kesehatan memiliki distribusi nilai sebesar 0,100.

2. Nilai koefisien regresi variabel Pendapatan Asli Daerah (PAD) (X1) adalah sebesar 0,396, hal ini berarti bahwa ketika terjadi peningkatan nilai variabel PAD sebesar satu satuan, maka variabel belanja modal kesehatan akan mengalami kenaikan sebesar 0,396. 
3. Nilai koefisien regresi variabel Dana Alokasi Umum (DAU) (X2) bernilai -0,284, hasil ini mengindikasikan bahwa ketika variabel DAU mengalami kenaikan sebesar satu satuan, maka variabel belanja modal kesehatan akan menurun sebesar -0,284.

4. Koefisien regresi variabel Dana Alokasi Khusus (DAK) (X3) menunjukkan nilai sebesar 0,220, hasil ini mengandung arti bahwa ketika variabel DAK meningkat satu satuan, maka variabel belanja modal kesehatan akan meningkat sebesar 0,220.

\subsection{Hasil Uji Hipotesis Simultan (Uji F)}

Tabel 7. Hasil Uji Hipotesis Simultan (Uji F)

\begin{tabular}{|c|c|c|c|}
\hline Variabel & $\begin{array}{c}\text { Alph } \\
\mathbf{a}\end{array}$ & Sig. & Note \\
\hline $\mathrm{X} 1, \mathrm{X} 2, \& \mathrm{X} 3$ & 0,01 & $\begin{array}{c}0,00 \\
* * *\end{array}$ & Ha Diterima \\
\hline
\end{tabular}

Dari tabel di atas yang merupakan hasil uji Anova diperoleh nilai signifikansi variabel Pendapatan Asli Daerah (PAD) (X1), Dana Alokasi Umum (DAU) (X2), dan Dana Alokasi Khusus (DAK) (X3) terhadap variabel belanja modal kesehatan (Y) secara simultan. Nilai signifikansi hasil uji Anova adalah sebesar 0,00. Nilai ini lebih kecil daripada 0,01 yang menjadi parameter toleransi kesalahan (tingkat kepercayaan 1\%). Berdasarkan hasil perbandingan nilai signifikansi dengan nilai alpha, maka dapat disimpulkan bahwa secara simultan variabel PAD (X1), DAU (X2), dan DAK (X3) terhadap variabel belanja modal kesehatan (Y).

\subsection{Hasil Uji Koefisien Determinasi}

Tabel 8. Hasil Uji Koefisien Determinasi

\begin{tabular}{lcc}
\hline \hline \multicolumn{1}{c}{ Indikator } & Nilai & $\mathbf{\%}$ \\
\hline & 0,473 & 47 \\
Adjusted $R$ Square & & $\%$ \\
\hline $\begin{array}{l}\text { Sumber: Data output SPSS } \\
\text { diolah }\end{array}$ &
\end{tabular}

Tabel 8 adalah hasil dari uji koefisien determinasi. Pada tabel tersebut diperoleh nilai Adjusted $R$ Square sebesar 0,473. Hasil ini menunjukkan bahwa variabel Pendapatan Asli Daerah (PAD) (X1), Dana Alokasi Umum (DAU) (X2), dan Dana Alokasi Khusus (DAK) (X3) mampu menjelaskan variabel belanja modal kesehatan (Y) 47,3\%. Sementara itu, 52,7 \% sisanya adalah faktor lain yang tidak diobservasi ke dalam model penelitian.

\section{KESIMPULAN}

Berdasarkan uraian dari awal hingga pada bagian akhir pembahasan, maka diperoleh beberapa kesimpulan berikut: 
1. Secara simultan variabel Pendapatan Asli Daerah (PAD) (X1), Dana Alokasi Umum (DAU) (X2), dan Dana Alokasi Khusus (DAK) (X3) berpengaruh signifikan terhadap belanja modal kesehatan (Y).

2. Secara parsial ketiga variabel independen menunjukkan pengaruh yang signifikan terhadap belanja modal kesehatan.

3. Variabel Pendapatan Asli Daerah (PAD) (X1) menunjukkan pengaruh positif signifikan terhadap belanja modal kesehatan.

4. Variabel Dana Alokasi Umum (DAU) (X2) memiliki pengaruh negatif signifikan terhadap belanja modal kesehatan.

5. Variabel Dana Alokasi Khusus (DAK) menunjukkan pengaruh positif signifikan terhadap belanja modal kesehatan.

6. Intensitas pengaruh yang ditunjukkan oleh hasil uji koefisien determinasi menunjukkan kemampuan variabel independen untuk menjelaskan variabel belanja modal kesehatan sebesar $47,3 \%$, sementara sisanya sebesar 52,7 \% dipengaruhi faktor lain di luar model penelitian.

Bagi peneliti selanjutnya, disarankan untuk memperbanyak jumlah sampel yang diobservasi, serta meneliti faktor lain seperti alokasi dana bagi hasil, dana insentif desa serta variabel lainnya.

\section{DAFTAR PUSTAKA}

Eksandy, A., Hakim, M. Z., \& Ekawati. (2018). Pengaruh Pendapatan Asli Daerah, Dana Alokasi Umum, dan Dana Alokasi Khusus Terhadap Belanja Modal (Pada Pemerintah Provinsi Banten Periode 2011-2015). Competitive Jurnal Akuntansi Dan Keuangan, (2009), 85-94. Retrieved from http://jurnal.umt.ac.id/index.php/competitive/article/view/917/582

Gani, W., \& Kristanto, S. B. (2013). Pengaruh Dana Alokasi Umum dan Khusus terhadap Belanja Daerah pada Kabupaten/Kota di Pulau Sumatera. Jurnal InFestasi, 9(2), 115-122.

Jensen, M. C., \& Meckling, W. H. (1976). Theory of the firm: Managerial behavior, agency costs and ownership structure. Journal of Financial Economics, 3(4), 305-360. https://doi.org/10.1016/0304-405X(76)90026-X

Kamayanti, A. (2016). Metodologi Penelitian Kualitatif Akuntansi Pengantar Religiositas Keilmuan. Malang: Yayasan Rumah Peneleh.

Martini, K., \& Dwirandra, A. A. N. B. (2018). Pengaruh Kinerja Keuangan Daerah Terhadap Alokasi Belanja Modal di Provinsi Bali. E-Jurnal Manajemen Universitas Udayana, 7(9), 4713. https://doi.org/10.24843/ejmunud.2018.v07.i09.p04

Nuriyanto. (2014). Penyelenggaraan Pelayanan Publik Di Indonesia , Sudahkah Berlandaskan Konsep "Welfare State "? Jurnal Konstitusi, 11(3), 429-253.

Palupi, F. A. D., \& Sulardi. (2018). Faktor-Faktor Yang Memengaruhi Perubahan Alokasi Belanja Modal. Jurnal Akuntansi, 6(1), 40-51. https://doi.org/10.24964/ja.v6i1.563

Sari, D. M. M. Y., \& Wirama, D. G. (2018). Pengaruh PAD, DAU dan DAK pada Alokasi Belanja Modal dengan Pendapatan Per Kapita Sebagai Pemoderasi. E-Jurnal Akuntansi, 22(59), 2065. https://doi.org/10.24843/eja.2018.v22.i03.p16

Sholikhah, I., \& Wahyudin, A. (2014). Analisis Belanja Modal Pada Pemerintah Kabupaten/Kota Di Jawa. Accounting Analysis Journal, 3(4), 553-562. https://doi.org/ISSN 2252-6765 
Sudika, i komang, \& Budiartha, i ketut. (2017). Pengaruh Pajak Daerah, Retribusi Daerah, Dana Alokasi Umum dan Dana Alokasi Khusus Pada Belanja Modal Provinsi Bali. E-Journal Akuntansi Universitas Udayana, 21(2), 1689-1718.

Sujarweni, V. W. (2015). Metode Penelitian Bisnis dan Ekonomi.

Widiasih, N. N., \& Gayatri. (2017). Pengaruh Pendapatan Asli Daerah , Dana Alokasi Umum , Dana Bagi Hasil Pada Belanja Modal Kabupaten / Kota Di Provinsi Bali. E-Journal Akuntansi Universitas Udayana, 18(3), 2143-2171. 